\title{
Effects of Endothelin on Renal Function in Newborn Rabbits ${ }^{1}$
}

\author{
D. S. SEMAMA. ${ }^{2}$ M. THONNEY, J.-P. GUIGNARD, AND J.-B. GOUYON
}

Service de Pédiatrie. Centre Hospitalier Universitaire Vaudois, 1011 Lausanne. Switzerland

\begin{abstract}
The renal effects of endothelin-1 were investigated in 16 anesthetized and mechanically ventilated newborn rabbits. Renal blood flow and glomerular filtration rate were determined by the clearance of para-aminohippuric acid and inulin, respectively. Each animal acted as its own control. In eight newborn rabbits, a bolus injection of $5 \mathrm{nmol} \cdot \mathrm{kg}^{-1}$ of endothelin-1 caused an initial fall in mean arterial blood pressure followed by a gradual, significant increase in mean arterial blood pressure that lasted for $45 \mathrm{~min}$. The dramatic increase in renal vascular resistance $(+28 \pm 4 \%)$ induced by endothelin led to a fall in glomerular filtration rate $(-12 \pm 4 \%)$ and renal blood flow $(-16 \pm 3 \%)$. In spite of the reduction of glomerular filtration rate and renal blood flow, urine flow and sodium excretion rates increased significantly $(+20 \pm 5 \%$ and +49 $\pm 9 \%$, respectively). In eight additional newborn rabbits, a bolus injection of $1 \mathrm{nmol} \cdot \mathrm{kg}^{-1}$ of endothelin-a dose that usually induces marked renal and systemic vasoconstriction in adult models-did not affect systemic or renal hemodynamics. In conclusion, endothelin induces renal and systemic vasoconstriction and affects water and sodium homeostasis during the neonatal period. These effects occur under higher doses than those used in adult animals. This age difference in systemic and renal responsiveness is probably mediated by receptor immaturity and/or interference of high levels of counteracting hormones present during the neonatal period. (Pediatr Res 34: 120-123, 1993)
\end{abstract}

\section{Abbreviations}

GFR, glomerular filtration rate
RBF, renal blood flow
RPF, renal plasma flow
FF, filtration fraction
MBP, mean blood pressure
RVR, renal vascular resistance
PAH, paraaminohippuric acid
V, urine flow rate
U $_{\mathrm{NA}}$, urinary sodium excretion

The immature kidney is exposed to various vasoactive systems such as the renin-angiotensin system, intrarenal adenosine, the prostaglandins, and atrial natriuretic peptide, which are hyper-

Received December 17, 1992; accepted March 16, 1993.

Correspondence and reprint requests: J.-P. Guignard, M.D., Service de Pédiatrie CHUV, 1011 Lausanne, Switzerland.

Supported by Grant 32-26395.89/2 of the Swiss National Science Foundation. Dr. D. Semama was the recipient of a grant of the Foundation du 450e Anniversaire. Universite de Lausanne, Switzerland.

Presented in part at the Annual Meeting of the Swiss Society of Nephrology. Aarau, Switzerland, December 1992.

${ }_{2}^{2}$ Present address: Service de Pédiatrie 2 et Laboratoire de Néphrologie-Hémaphérèse-Transplantation, CHRU de Dijon, 21000 Dijon. France. active in the neonatal period (1). Endothelin, a potent vasoconstrictor peptide, has been recently isolated from cultured porcine endothelial cells (2). This peptide is approximately 100 times more potent than noradrenaline and 1000 times more active than neuropeptide $\mathrm{Y}$ on a molar basis in the rabbit microvasculature system (3). The effects of endothelin on renal function have been well described in adult animals: rats (4-6), dogs $(4,7)$, and rabbits (8). In these experiments, a bolus injection of endothelin induced a slow-developing and long-lasting vasoconstriction of renal afferent and efferent arterioles that led to a dramatic decrease in RBF and GFR (4-7). Little information is as yet available concerning the renal hemodynamic effects of endothelin in the neonatal period (9). This study was therefore undertaken to evaluate the renal actions of endothelin in newborn rabbits, an animal model whose renal maturation shows close similarities to that of premature infants $(10,11)$.

\section{MATERIALS AND METHODS}

Experiments were performed in 16 newborn New Zealand White rabbits aged 5 to $8 \mathrm{~d}$ and weighing 76 to $136 \mathrm{~g}$. Animals were born by spontaneous vaginal delivery and afterwards housed with the maternal rabbit and breast-fed. The animals were divided into two groups. The animals of group $1(n=8)$ received a dose of $1 \mathrm{nmol} \cdot \mathrm{kg}^{-1}$ of endothelin, whereas those of group 2 received $5 \mathrm{nmol} \cdot \mathrm{kg}^{-1}$

Experimental procedures. The animals were initially anesthetized with sodium pentobarbital $\left(25 \mathrm{mg} \cdot \mathrm{kg}^{-1}\right.$ intraperitoneally), supplemental small doses being thereafter given i.v. as required. The trachea was cannulated to allow mechanical ventilation with a mixture of air and oxygen (Rodent ventilator, model 683 , Harvard, Millis, MA). The femoral vessels and urinary bladder were catheterized for arterial blood sampling and monitoring of systemic blood pressure (Statham P23 ID pressure transducer recorded on a model $78205 \mathrm{D}$ pressure recorder, Hewlett-Packard Co., Palo Alto, CA, solute and drug infusion, and urine collection as previously described (12,13). Body temperature was also continuously recorded by an intraesophageal thermometer (Digital thermometer, Poliak and Gramiger, EPFL, Lausanne. Switzerland) and maintained around $38^{\circ}$ and $39^{\circ} \mathrm{C}$ by means of an infrared lamp and a warming operating table. After completion of the surgical procedure, a priming dose of inulin $\left(80 \mathrm{mg} \cdot \mathrm{kg}^{-1}\right)$ and PAH $\left(1.25 \mathrm{mg} \cdot \mathrm{kg}^{-1}\right)$ was administered and a sustained infusion given to maintain constant plasma inulin and PAH concentrations. Throughout the experiment, the infusion rate was $1 \mathrm{~mL} / \mathrm{h} / 100 \mathrm{~g}$ body weight, using a constant infusion pump (Perfusor EDL 2, Braun, Melsungen, Germany). The infusate contained, per L: $100 \mathrm{mmol}$ of $\mathrm{NaCl}, 50 \mathrm{mmol}$ of $\mathrm{NaHCO}_{3}, 5 \mathrm{mmol}$ of $\mathrm{KCl}, 50 \mathrm{~g}$ of mannitol, $3 \mathrm{~g}$ of inulin, and $150 \mathrm{mg}$ of PAH. Approximately $45 \mathrm{~min}$ were spent for animal preparation and $90 \mathrm{~min}$ for subsequent equilibration.

Experimental protocol. After the equilibration period, the experimental protocol started with a control period of $60 \mathrm{~min}$. At the end of the control period, the animals received a bolus injection of 1 or $5 \mathrm{nmol} \cdot \mathrm{kg}^{-1}$ of endothelin (human Endothelin- 
1, Peptides International, Louisville, KY). Renal function and blood pressure were then further assessed during two 30-min periods (I and II). Each animal acted as its own control. For the control period, two timed urinary collections of $30 \mathrm{~min}$ each were obtained with blood sampling $(0.4 \mathrm{~mL})$ at the midpoint. For each of the two subsequent periods, one timed urinary collection of $30 \mathrm{~min}$ was obtained with blood sampling $(0.4 \mathrm{~mL})$ at the midpoint. Eighty $\mu \mathrm{L}$ of blood were used for immediate gases, hematocrit, and protein levels determination. The remainder was centrifuged and the red blood cells immediately reconstituted in up to $0.4 \mathrm{~mL}$ of human albumin and returned to the animal. Plasma and urine samples were kept at $-20^{\circ} \mathrm{C}$ for subsequent analysis of inulin. $\mathrm{PAH}$, and $\mathrm{Na}$. The rabbits were thereafter killed with a lethal dose of pentobarbital.

Analytical procedures. Urine volume was calculated from the change in weight of the preweighed tubes without correction for specific gravity. Arterial blood for $\mathrm{pH}, \mathrm{PCO}_{2}, \mathrm{PO}_{2}$, hematocrit. and protein levels was collected anaerobically in heparinized capillary tubes. Blood gas determinations were performed with a $\mathrm{pH} /$ blood gas analyzer (Gas analyzer 168. Corning. Essex, UK). The automatic anthrone (14) and the Bratton and Marshall (15) methods were used for the determination of inulin and $\mathrm{PAH}$ concentrations, respectively (Autoanalyzer II. Technicon Instrument Corporation. Tarrytown, NY). Sodium was measured by flame photometry (Flame-Photometer 943, Instrumentation Laboratory, Lexington, MA). Plasma protein concentration was estimated from the plasma index of refraction, using a temperature-compensated refractometer (AOTS meter, American Optical, Buffalo, NY).

Data analysis. The renal clearances of inulin $\left(\mathrm{C}_{\mathrm{In}_{n}}\right)$ and $\mathrm{PAH}$ $\left(\mathrm{C}_{\mathrm{PAH}}\right)$ were calculated from standard equations and used as indices of GFR and RPF, respectively. A renal PAH extraction ratio $\left(E_{P A H}\right)$ of 0.55 , as previously determined in our laboratory (10), was used to calculate RBF. RBF. RVR. FF, and $U_{N a} V$ were calculated from the following equations:

$$
\begin{gathered}
\mathrm{RBF}\left(\mathrm{mL} \cdot \mathrm{kg}^{-1} \cdot \mathrm{min}^{-1}\right)=\mathrm{C}_{\mathrm{PAH}} /\left[\mathrm{E}_{\mathrm{PAH}} \times(1-\text { hematocrit })\right] \\
\mathrm{RVR}\left(\mathrm{mm} \mathrm{Hg} \cdot \mathrm{mL}^{-1} \cdot \mathrm{kg} \cdot \mathrm{min}\right)=\mathrm{MBP} / \mathrm{RBF}
\end{gathered}
$$

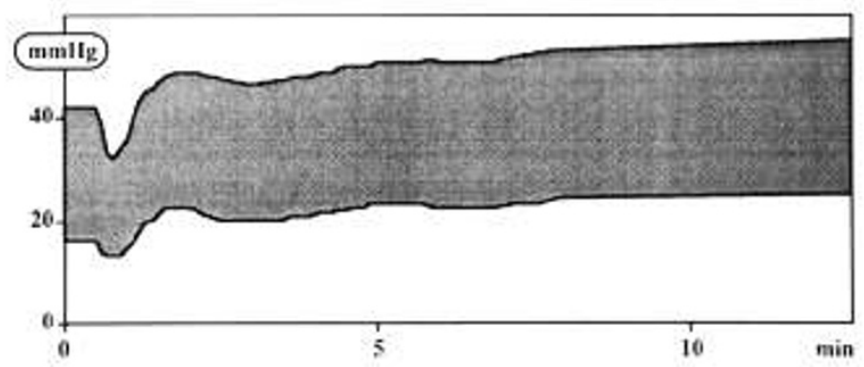

Fig. 1. Effects of endothelin $\left(5 \mathrm{nmol} \cdot \mathrm{kg}^{-1}\right)$ on arterial blood pressure. Endothelin bolus injection induced an initial drop in MBP followed by a gradual increase.

$$
\begin{gathered}
\mathrm{FF}(\%)=\mathrm{GFR} / \mathrm{RPF} \\
\mathrm{U}_{\mathrm{Na}} \mathrm{V}\left(\mu \mathrm{mol} \cdot \mathrm{kg}^{-1} \cdot \mathrm{min}^{-1}\right)=\mathrm{Na} \text { urine concentration } \\
\times \text { urine flow rate }
\end{gathered}
$$

The data obtained from the two control periods were averaged. The effects of endothelin on hemodynamics and renal functions were assessed statistically by multiple paired $t$ test. a Bonferroni adjustment being used so as to assure an overall type I error rate of $<0.05$. Comparisons between group 1 and group 2 were performed by unpaired $t$ test: $p$ values $<0.05$ were considered statistically significant. All data are expressed as means \pm SEM.

\section{RESULTS}

Postnatal age, body weight. $\mathrm{pH}$. arterial oxygen tension, arterial carbon dioxide tension, protein plasma levels, hematocrit, MBP, and renal function during the control period were not statistically different between the two groups of newborn rabbits. Blood $\mathrm{pH}$. arterial oxygen tension, arterial carbon dioxide tension, protein plasma levels, and hematocrit did not vary significantly throughout the study in both groups (Table 1).

Effect of endothelin on MBP. The i.v. bolus injection of 1 $\mathrm{nmol} \cdot \mathrm{kg}^{-i}$ of endothelin did not induce changes in MBP. By contrast, the i.v. bolus injection of $5 \mathrm{nmol} \cdot \mathrm{kg}^{-1}$ of endothelin caused an initial fall in MBP (Fig. 1) followed by a gradual. significant increase in MBP reaching its maximum level $15 \mathrm{~min}$ after injection ( $43 \pm 2$ versus $34 \pm 2 \mathrm{~mm} \mathrm{Hg} ; p<0.001)$. MBP then decreased but remained elevated $45 \mathrm{~min}$ after the bolus ( 37 $\pm 2 \mathrm{~mm} \mathrm{Hg:} p<0.01$ ) (Table 1).

Effects of endothelin on renal hemodynamics and water and sodium excretion. Table 2 shows the absolute values observed for the renal parameters in the control and experimental periods in both groups.

In group 1, the i.v. bolus injection of $1 \mathrm{nmol} \cdot \mathrm{kg}^{-1}$ of endothelin did not induce any change in renal hemodynamics during both periods. It significantly increased sodium excretion in period II (Table 2).

In group 2, V, GFR, RBF, and FF did not vary significantly during the first $30 \mathrm{~min}$ after the administration of endothelin (period I), whereas RVR rose by $40 \pm 9 \%(p<0.01)$. During the subsequent period (period II). GFR $(-12 \pm 4 \%)$ and RBF $(-16 \pm 3 \%)$ decreased significantly, whereas $\mathrm{V}(+20 \pm 5 \% ; p<$ $0.01)$ and $\mathrm{U}_{\mathrm{Na}} \mathrm{V}(+49 \pm 9 \% ; p<0.01)$ increased markedly (Fig. 2). RVR remained elevated throughout period II.

\section{DISCUSSION}

This study was undertaken to determine the effects of endothelin on systemic and renal hemodynamics in newborn rabbits. using two different doses of 1 and $5 \mathrm{nmol} \cdot \mathrm{kg}^{-1}$. In this model, a marked systemic and renal vasoconstriction was only seen with the higher dose of endothelin. The response of blood pressure was biphasic. This pattern has been reported by others $(5,16)$ especially when high doses of endothelin were used. The initial

Table 1. Effects of endothelin on MBP. pH, arterial oxygen tension, arterial carbon dioxide tension, protein levels, and hematocrit in group $1\left(1 \mathrm{mmol} \cdot \mathrm{kg}^{-1}\right)$ and in group $2\left(5 \mathrm{mmol} \cdot \mathrm{kg}^{-1}\right)^{*}$

\begin{tabular}{cllcccrr}
\hline Group & Period & $\begin{array}{c}\mathrm{MBP} \\
(\mathrm{mm} \mathrm{Hg})\end{array}$ & $\mathrm{pH}$ & $\begin{array}{c}\text { PaO } \\
(\mathrm{kPa})\end{array}$ & $\begin{array}{c}\text { Pac(o) } \\
(\mathrm{kPa})\end{array}$ & $\begin{array}{c}\text { Protein } \\
\left(\mathrm{g} \cdot \mathrm{L}^{-1}\right)\end{array}$ & $\begin{array}{c}\mathrm{Hct} \\
(\mathrm{L})\end{array}$ \\
\hline 1 & Control & $36 \pm 2$ & $7.51 \pm 0.01$ & $15.7 \pm 0.4$ & $4.7 \pm 0.1$ & $31.4 \pm 5.5$ & $0.29 \pm 0.04$ \\
& I & $38 \pm 2$ & $7.50 \pm 0.01$ & $15.6 \pm 0.6$ & $4.8 \pm 0.2$ & $30.6 \pm 2.2$ & $0.29 \pm 0.04$ \\
& II & $37 \pm 2$ & $7.51 \pm 0.01$ & $15.9 \pm 0.7$ & $4.3 \pm 0.2$ & $30.3 \pm 2.1$ & $0.31 \pm 0.01$ \\
& Control & $34 \pm 2$ & $7.51 \pm 0.01$ & $16.1 \pm 0.6$ & $4.8 \pm 0.1$ & $31.6 \pm 1.9$ & $0.31 \pm 0.01$ \\
& I & $43 \pm 2 \dagger$ & $7.50 \pm 0.01$ & $16.4 \pm 1.0$ & $4.6 \pm 0.2$ & $30.8 \pm 1.9$ & $0.31 \pm 0.01$ \\
& II & $37 \pm 2 \ddagger$ & $7.51 \pm 0.01$ & $17.0 \pm 0.7$ & $4.6 \pm 0.1$ & $29.8 \pm 1.8$ & $0.29 \pm 0.01$ \\
\hline
\end{tabular}

* The values were measured at the midpoint of each period: $15 \mathrm{~min}$ after endothelin bolus injection for period $\mathrm{I}$ and $45 \mathrm{~min}$ after endothelin bolus injection for period II. $\mathrm{PaO}_{2}$, arterial oxygen tension; $\mathrm{PaCO}_{2}$, arterial carbon dioxide tension: Hct. hematocrit.

$+p<0.001$ significant difference when comparing values with the control period of the same group.

$\ddagger p<0.01$ significant difference when comparing values with the control period of the same group. 
Table 2. Effects of endothelin on renal hemodynamics and water and sodium excretion in group $1\left(1 \mathrm{nmol} \cdot \mathrm{kg}^{-1}\right)$ and in group $2\left(5 \mathrm{nmol} \cdot \mathrm{kg}^{-1}\right)$

\begin{tabular}{clcccccc}
\hline Group & Period & $\begin{array}{c}\mathrm{V} \\
\left(\mathrm{mL} \cdot \mathrm{kg}^{-1} \cdot \mathrm{min}^{-1}\right)\end{array}$ & $\begin{array}{c}\mathrm{GFR} \\
\left(\mathrm{mL} \cdot \mathrm{kg}^{-1} \cdot \mathrm{min}^{-1}\right)\end{array}$ & $\begin{array}{c}\mathrm{RBF} \\
\left(\mathrm{mL} \cdot \mathrm{kg}^{-1} \cdot \mathrm{min}^{-1}\right)\end{array}$ & $\begin{array}{c}\mathrm{RVR} \\
\left(\mathrm{mm} \mathrm{Hg} \cdot \mathrm{mL}^{-1} \cdot \mathrm{kg} \cdot \mathrm{min}\right)\end{array}$ & $\begin{array}{c}\mathrm{FF} \\
(\%)\end{array}$ & $\begin{array}{c}\mathrm{U}_{\mathrm{NaV}} \mathrm{V} \\
\left(\mu \mathrm{mol} \cdot \mathrm{kg}^{-1} \cdot \mathrm{min}^{-1}\right)\end{array}$ \\
\hline I & Control & $0.081 \pm 0.005$ & $2.13 \pm 0.18$ & $20.3 \pm 2.1$ & $1.91 \pm 0.12$ & $27.9 \pm 1.8$ & $2.02 \pm 0.61$ \\
& I & $0.095 \pm 0.006$ & $2.26 \pm 0.22$ & $20.2 \pm 2.5$ & $2.03 \pm 0.17$ & $29.8 \pm 2.2$ & $2.71 \pm 0.94$ \\
& II & $0.094 \pm 0.009$ & $1.95 \pm 0.22$ & $20.3 \pm 3.7$ & $2.13 \pm 0.27$ & $27.6 \pm 2.3$ & $3.01 \pm 0.90^{*}$ \\
2 & Control & $0.085 \pm 0.008$ & $2.17 \pm 0.22$ & $21.0 \pm 1.8$ & $1.69 \pm 0.10$ & $27.1 \pm 1.5$ & $5.48 \pm 1.74$ \\
& I & $0.106 \pm 0.008$ & $2.06 \pm 0.18$ & $18.8 \pm 1.6$ & $2.35 \pm 0.17 \dagger$ & $29.0 \pm 1.1$ & $4.93 \pm 0.88$ \\
& II & $0.103 \pm 0.010 \dagger$ & $1.95 \pm 0.26^{*}$ & $17.7 \pm 1.7 \dagger$ & $2.16 \pm 0.13 \ddagger$ & $28.1 \pm 1.8$ & $7.24 \pm 1.91 \dagger$ \\
\hline
\end{tabular}

$* p<0.05$ significant difference when comparing values with the control period of the same group.

$+p<0.01$, significant difference when comparing values with the control period of the same group.

$\ddagger p<0.001$ significant difference when comparing values with the control period of the same group.

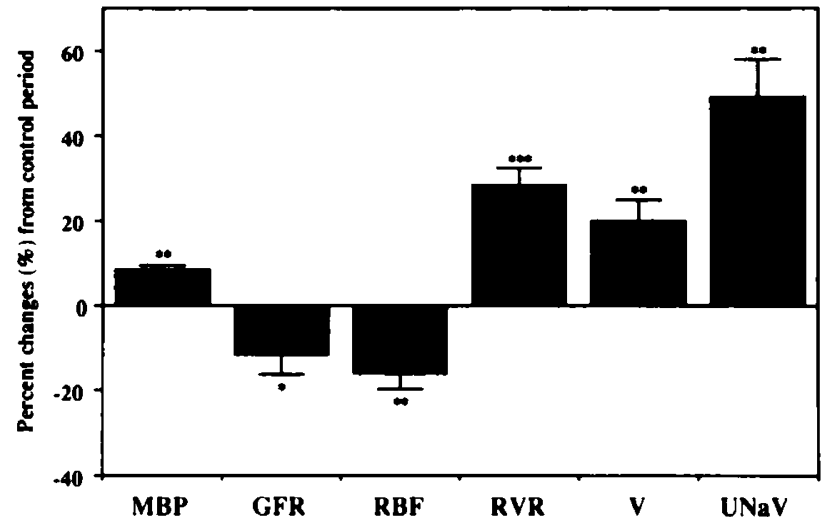

Fig. 2. Effects of endothelin ( $\left.5 \mathrm{nmol} \cdot \mathrm{kg}^{-1}\right)$ on MBP, renal hemodynamics, and water and sodium excretion in period II. ${ }^{*}, p<0.05 ;{ }^{* *}, p$ $<0.011^{* * *}, p<0.001$, significant difference when values are compared with control period.

decrease in MBP has been ascribed to the release of nitric oxide induced by exogenous endothelin $(17,18)$. As compared with adult animals of other species $(2,5)$, our model presented with a different response to endothelin injection: the higher value appeared earlier ( $15 \mathrm{~min}$ instead of 30 ), and the duration of elevated blood pressure was shorter ( 45 min instead of more than 60 ). This latter finding could be explained by the existence, during the neonatal period, of high circulating levels of atrial natriuretic peptide $(19,20)$. Such levels could, as suggested by the observation of Semmekrot et al. (21) that the administration of atrial natriuretic peptide to newborn rabbits induced a significant decrease in MBP, produce systemic vasodilatation and so counteract the effect of exogenous endothelin.

Injection of endothelin caused a marked elevation of RVR that remained high throughout the experiment. The increase in RVR did not seem to be pressure-dependent, because it persisted unchanged when MBP decreased toward normal values. This confirms other reports showing that the intrarenal infusion of endothelin induced intense renal vasoconstriction without changing MBP, thus pointing to a local action of endothelin on the renal microcirculation $(6,22)$.

In spite of the immediate increase in RVR in period I, GFR and RBF did not change, probably because the high levels of blood pressure maintained blood flow and filtration through the vasoconstricted vessels. Such an observation has been made by King et al. (5) in aortic snare studies. The authors demonstrated that endothelin caused a fall in GFR and RPF in the snared kidney whereas GFR and RPF were preserved in the contralateral unsnared kidney, thus confirming the dependence of these parameters on systemic perfusion pressure. The relative decrease in MBP in period II, while RVR remained high, led to a fall in GFR and RBF. The predominant site of action of endothelin on renal vessels is still ill defined. In vivo experiments $(5,23)$ have suggested preferential efferent arteriolar vasoconstriction, whereas the occurrence of predominant afferent constriction was suggested by in vitro studies (24). This discrepancy could be explained by the in vivo release by endothelin of counterregulatory hormones such as nitric oxide $(17,18)$, prostacyclin $(25)$, or atrial natriuretic peptide (26). The nonsignificant increase in FF present in our experiments suggests, but does not prove, predominant efferent vasoconstriction.

In our experiments, noteworthy is the observation that $\mathrm{V}$ increased significantly in the presence of reduced GFR and RBF. A diuretic effect has been observed by others $(23,27)$ and ascribed to an inhibition by endothelin of arginine vasopressin-stimulated osmotic water permeability in inner medullary collecting ducts (28). This effect could also be ascribed, at least in part, to the increased salt excretion observed in our experiments $(+49 \pm 9 \%$; $p<0.01)$. Such a natriuretic effect has been described by others $(5,27,29)$ and found to be, at least in part, pressure related (5). In our study, pressure is unlikely to be responsible for the natriuresis, because the increase in $\mathrm{U}_{\mathrm{Na}} \mathrm{V}$ was also observed in group 1, where MBP did not change significantly. Increased sodium excretion could be due to an inhibition of $\mathrm{Na}^{+} / \mathrm{K}^{+}$ ATPase, located in the inner medullary collecting duct cells (29). Although Uusimaa et al. (30) showed that endothelin was able to release atrial natriuretic peptide from cultured neonatal cardiac myocytes, this agent is unlikely to be responsible for the natriuretic and diuretic effects observed in our study. Indeed, in experiments performed by Semmekrot $e t$ al. (21) in newborn rabbits, injection of exogenous atrial natriuretic peptide, reaching levels of $1575 \pm 364 \mathrm{pg} \cdot \mathrm{mL}^{-1}$, failed to increase either sodium excretion or urine flow rate.

It is of interest to note that in the newborn rabbit a dose of 1 $\mathrm{nmol} \cdot \mathrm{kg}^{-1}$ of endothelin, which usually induces severe renal and systemic vasoconstriction in adult models $(5,16)$, failed to change systemic or renal hemodynamics (group 1). This age difference in systemic and renal responsiveness is probably mediated by receptor immaturity or interference of counteracting hormones.

In conclusion, the present results demonstrate that endothelin is able to induce renal and systemic vasoconstriction and to affect water and sodium homeostasis during the neonatal period. The renal hemodynamic effects of endothelin mimic some of the changes induced by acute hypoxemia in animal models $(10,12)$ as well as in human newborns (31). This observation suggests that endothelin could be one of the mediators of the hypoxemiainduced renal vasoconstriction.

Acknowledgment. The authors thank Dr. E. G. John, Chicago, for valuable discussion of the results.

\section{REFERENCES}

1. Guignard J-P, Gouyon J-B, John EG 1991 Vasoactive factors in the immature kidney. Pediatr Nephrol 5:443-446

2. Yanagisawa M, Kurihara H, Kimura S, Tomobe Y, Kobayashi M, Mitsui Y. Yazaki Y, Goto K. Masaki T 1988 A novel potent vasoconstrictor peptide produced by vascular endothelial cells. Nature 332:411-415

3. Brain SD, Tippins JR, Williams TJ 1988 Endothelin induces potent microvascular constriction. Br J Pharmacol 95:1005-1007

4. Banks RO 1989 Cardiovascular and renal effects of endothelin in the dog and in the rat. Kidney Int 35:309(abstr) 
5. King AJ, Brenner BM. Anderson S 1989 Endothelin: a potent renal and systemic vasoconstrictor peptide. Am J Physiol 256:F1051-F1058

6. Kon V, Yoshioka T, Fogo A, Ichikawa I 1989 Glomerular actions of endothelin in vivo. J Clin Invest 83:1762-1767

7. Miller WL, Redfield M, Burnett JC 1989 Endothelin constricts the renal circulation and stimulates renin in vivo. Kidney Int 35:317(abstr)

8. Miyamori I, Itoh Y, Matsubara T, Koshida H, Takeda R 1990 Systemic and regional effects of endothelin in rabbits: effects of endothelin antibody. Clin Exp Pharmacol Physiol 17:691-696

9. Bhat R, John E, Chari G, Fornell L, Raju T, Shankararao R, Vidyasagar D 1992 Endothelin 1-dose dependent effect on renal function and hemodynamics in piglets. Pediatr Nephrol 6:C104(abstr)

10. Gouyon J-B, Vallotton M. Guignard J-P 1987 The newborn rabbit: a model for studying hypoxemia-induced renal changes. Biol Neonate 52:115-120

11. Vallotton M 1984 Maturation de la fonction rénale chez le lapin nouveau-né effet de l'hypoxemie. Thesis, Lausanne University Medical School, Switzerland

12. Gouyon J-B, Guignard J-P 1988 Theophylline prevents the hypoxemia induced renal hemodynamic changes in rabbits. Kidney Int 33:1078-1083

13. Gouyon J-B, Amaud M, Guignard J-P 1988 Renal effects of low-dose aminophylline and enprofylline in newborn rabbits. Life Sci 42:1271-1278

14. Wright HK. Gann DS 1966 An automatic method for determination of inulin in plasma and urine. J Lab Clin Med 67:689-693

15. Bratton AC, Marshall EK 1939 A new coupling component for sulfanilamide determination. J Biol Chem 128:537-550

16. Wright CE. Fozard JR 1988 Regional vasodilatation is a prominent feature of the haemodynamic response to endothelin in anaesthetized, spontaneously hypertensive rats. Eur J Pharmacol 155:201-203

17. De Nucci G. Thomas $R$, D'Orleans-Juste $P$. Antunes E, Walder C, Warner TD, Vane JR 1988 Pressor effects of circulating endothelin are limited by its removal in the pulmonary circulation and by the release of prostacyclin and endothelium-derived relaxing factor. Proc Natl Acad Sci USA 85:97979800

18. Ito S, Juncos LA, Nushiro N. Johnson CS, Carretero OA 1991 Endotheliumderived relaxing factor modulates endothelin action in afferent arterioles. Hypertension 17:1052-1056
19. Kikuchi K Shiomi M, Horie K, Ohie T Nakao K, Imura H Mikawa H 1988 Plasma atrial natriuretic polypeptide concentration in healthy children from birth to adolescence. Acta Paediatr Scand 77:380-384

20. Yamaji T. Hirai N. Ishibashi M. Takaku F, Yanaihara T, Nakayama T 1986 Atrial natriuretic peptide in umbilical cord blood: evidence for a circulating hormone in human fetus. J Clin Endocrinol Metab 63:1414-1417

21. Semmekrot BA. Wiesel PH, Monnens LAH. Guignard J-P 1990 Age differences in renal response to atrial natriuretic peptide in rabbits. Life Sci 46:849-856

22. Katoh T, Chang H, Okuda T, Uchida S, Kurokawa K 1989 Endothelin decreases urine volume, GFR, and RPF by its direct action on the kidney. but does not affect mesangial cell function. Kidney Int 35:313(abstr)

23. Badr KF, Murray JJ, Breyer MD. Takahashi K, Inagami T, Harris RC 1989 Mesangial cell, glomerular and renal vascular responses to endothelin in the rat kidney. J Clin Invest 83:336-342

24. Loutzenhiser R, Epstein M, Hayashi K 1989 Endothelin induces a predominant afferent arteriolar vasoconstriction that is reversed by nifedipine. Kidney Int 35:315(abstr)

25. Rae GA. Trybulec G. De Nucci G, Vane JR 1989 Endothelin-1 release eicosanoids from rabbit isolated perfused kidney and spleen. $J$ Cardivasc Pharmacol 13(suppl 5):S89-S92

26. Katoh T, Chang H, Uchida S, Okuda T, Kurokawa K 1990 Direct effects of endothelin in the rat kidney. Am J Physiol 258:F397-F402

27. Takabatake T, Ise T, Ohta K, Kobayashi K-I 1991 Endothelin effects on renal function and tubuloglomerular feedback. Kidney Int 39(suppl 32):S122S124

28. Oishi R, Nonoguchi H, Tomita K, Marumo F 1991 Endothelin-1 inhibits AVP-stimulated osmotic water permeability in rat inner medullary collecting duct. Am J Physiol 261:F951-F956

29. Zeidel ML. Brady HR, Kone BC, Gullans SR. Brenner BM 1989 Endothelin, a peptide inhibitor of $\mathrm{Na}^{+}-\mathrm{K}^{+}$-A TPase in intact renal tubular epithelial cells. Am J Physiol 257:C1 101-C1107

30. Uusimaa PA, Hassinen IE, Vuolteenaho O Ruskoaho H 1992 Endothelin induced atrial natriuretic peptide release from cultured neonatal cardiac myocytes: the role of extracellular calcium and protein kinase-C. Endocrinology 130:2455-2464

31. Guignard J-P. Torrado A, Mazouni SM. Gautier E 1976 Renal function in respiratory distress syndrome. J Pediatr 88:845-850 